\title{
CROATIAN GLAGOLITISM BETWEEN THE WEST AND THE EAST
}

\author{
Milan Mihaljević
}

DOI: 10.17846/CL.2017.10.1.190-197

\begin{abstract}
MIHALJEVIĆ, Milan. Croatian Glagolitism Between the West and the East. The article is an overview of the position and role of Croatian Glagolitism in the medieval European cultural sphere. The author first reviews the roots of the Croatian-Glagolitic literature based on Cyrillo-Methodian foundations and the routes by which Church Slavonic texts made their way to Croatia. After that, he describes the status of the Croatian Church Slavonic literature among the Slavic medieval cultures, its position between the European West and East and its mediating role as a transmitter of Western-European texts translated from Latin or Italian to other Slavic literatures. Finally, he outlines shortly the so-called Emmaus episode, i.e. the activity of the Croatian Glagolites among Western Slavs in the 14th and the 15th centuries, as well as the echoes of the Croatian Glagolitism in Western European countries in the Renaissance period.
\end{abstract}

Key words: Croatian Glagolitism, Cyrillo-Methodian tradition, Croatian medieval culture

Abstrakt: MIHALJEVIĆ, Milan. Chorvátsky hlaholizmus medzi Západom a Východom. Štúdia predstavuje prehlad o pozícii a úlohe chorvátskeho hlaholizmu v kultúrnom kontexte stredovekej Európy. Autor najskôr skúma korene chorvátskej hlaholskej literatúry, založenej na cyrilo-metodských základoch a zároveň cesty, akými sa cirkevnoslovanské texty dostali do Chorvátska. Následne opisuje status chorvátskej, cirkevnoslovanskej literatúry v rámci slovanských stredovekých kultúr, jej pozíciu medzi európskym západom a východom ako aj jej sprostredkujúcu rolu odovzdávatela západoeurópskych textov, ktoré boli preložené z latinčiny alebo taliančiny do iných slovanských literatúr. Napokon stručne načrtáva priebeh tzv. emauzskej epizódy, teda aktivity chorvátskych glagolašov na území západných európskych krajín v období renesancie.

Klúčové slová: chorvátsky hlaholizmus, cyrilo-metodská tradícia, chorvátska stredoveká kultúra

\section{ROOTS}

\subsection{Introduction}

Croatian medieval culture was unique in the Western European cultural sphere as it used three scripts (Latin, Glagolitic and Cyrillic) and three languages (Latin, Church Slavonic and Croatian). Church Slavonic Language as well as Glagolitic and Cyrillic scripts came to Croatia as part of the Cyrillo-Methodian tradition. It is commonly recognized today that late 9th or early 10th century was the beginning of the Croato-Glagolitic literature based on Cyrillo-Methodian foundations. It is possible that Croats had already come in contact with the Cyrillo-Methodian mission, but most experts believe that intensive and permanent contacts with this tradition were established after Methodius' death (Štefanić 1971, Petrović 1988, Birnbaum 1996). Church Slavonic texts made 
their way to Croatia by two alternative routes - first from the north, i.e. directly from Moravia and Panonia, and later from the south, i.e. from Macedonia by way of the intermediate regions of Duklja, Hum and Bosnia.

\subsection{The Northern Route}

The Vienna Folia from the eleventh or the beginning of the twelfth century are usually considered to represent the oldest testimony of the ties between the Moravian and the Croatian liturgical traditions, i.e. the oldest testimony of the northern route (Hercigonja 1975). It is highly probable that Old Church Slavonic texts of Gospels and Psalms also came to Croatia directly from Moravia/ Panonia, since the Croato-Glagolitic copies of these texts represent the oldest Cyrillo-Methodian translation without elements introduced later in Bulgaria and Macedonia (Vrana 1975, Moszyński 1986, Valjavec 1890, Mihaljević, Šimić 2013). The northern route ceased to function at the beginning of the 12th century, when Church Slavonic liturgy and tradition became extinct in Czech and Moravian territory. ${ }^{1}$

\subsection{The Southern Route}

It should be noted that the southern route and the contact with so-called Slavia Orthodoxa was not cut off after the Great Schism of 1054. Until the end of the Church Slavonic period (the middle of the 16th century), ${ }^{2}$ different texts were brought from Macedonia to Croatian literary centres by the southern route. In the first period, until the 12th century, every wave which came by the southern route brought the Glagolitic and the Cyrillic script, and in the second period (after 12th century) only the Cyrillic script (Fučic 1987, 19). Therefore, the most obvious trace of the southern route is the Cyrillic script. We know today that Croatian Glagolites ${ }^{3}$ were familiar, not only with Glagolitic and Latin, but also with the Cyrillic script. Cyrillic letters appear in many Croatian Glagolitic inscriptions from the oldest period (11th - 12th centuries), as well as in codices from the 14th and the 15th centuries. Some scribes wrote their notes and comments in western, Croatian type of the Cyrillic script (bosačnica). Sometimes they even began the note in Glagolitic and ended it in the Cyrillic script or vice versa (Nazor 1985). That a certain text has arrived by the southern route, can best be seen by its language. Particulary important in this respect are eastern Bulgarian elements which are traditionally called Preslavisms, because it is believed that they were introduced into the Old Church Slavonic texts in Preslav. The group of texts for which it has been established that they arrived in Croatia from the southeast (from Macedonia and Bulgaria) consists of Biblical texts, apocrypha, saintly legends and passions, homiletic texts, blessings and prayers, and tales (Mihaljević 2016). Of course, biblical, as well as liturgical texts in general, arrived from the southeast in the first period, before 12th century. A large number of Preslavisms occurs in the Acts of the Apostles and in the epistles, both in Missals and Breviaries, which means that Croatian Glagolites, before the appearance of plenary Missal and Breviary in the 13th century, had the book of Apostle which had arrived by the southern route. The close

\footnotetext{
After the extinction of Slavic liturgy in the Sazava monastery.

2 It is usually assumed that the Church Slavonic period ended in Croatia in 1561, when the priest Nikola Brozić from Omišalj on the island of Krk printed his Glagolitic breviary in Venice, which is the last book printed in the indigenuous Croatian recension of Church Slavonic. The period after that is called New Church Slavonic, and it is characterized in Croatia by the russification of liturgical texts. Cf. Gadžijeva et. al. $(2014,10-11)$.

3 Those from Dalmatia as well as those from Kvarner and Istria region.
} 
links of the Croatian Glagolitic Apostle with the Eastern Church tradition is confirmed by the fact that Croatian Glagolitic liturgical codices preserved some chapters which were not in use in the Western Church, but were characteristic for eastern, Greek and Slavic Apostles (Tandarić 1993, 310). In Old Testament books and in the Revelation, the situation varies from codex to codex and from text to text. In Genesis, Exodus, Deuteronomy, Book of the Kings, Ecclesiasticus, Book of the Prophet Isaiah, Small Prophets as well as in Revelation preslavisms occur mostly in the codices of the northern Krk-Istria group which are based on Greek translation. This shows that Old Church Slavonic translations of some Old Testament books had also reached Croatian territory by the southern route. Numerous apocryphal writings, as well as saintly legends and passions, had arrived to Croatian Glagolitic territory by the southern route, some of them in the second period, after 12th century. Some scholars connect their spreading from Macedonia to the northwest with the spreading of Bogomilism in the 11th - 12th centuries (Hercigonja 1975, Birnbaum 1996). In this way they came to Bosnia, and subsequently from there to Croatian Glagolitic centres. Some of these texts have been preserved in the oldest fragments from the transitional period of Croatian Glagolitism. ${ }^{4}$ They are very important for Palaeoslavistics, not only because they represent the oldest redaction of the Church Slavonic translations, but because they often belong to the oldest preserved Slavic copies of particular texts, and sometimes even the oldest (for example: the Budapest fragment of the Life of Simeon the Stylites from the 12th century, the fragment of the Life of St. Marina from Novo Mesto from the end of the 13th or the beginning of the 14th centuries, the Pazin fragments of the Obdormitio Deiparae and of the Acts of Andrew and Mathew in the city of cannibals from the beginning of the 14th century. Many of these texts had also been copied later ${ }^{5}$ in Glagolitic miscellanies from the 15 th -16 th centuries.

\section{THE STATUS OF THE CROATIAN GLAGOLITISM AMONG THE SLAVIC MEDIEVAL CULTURES}

Among Slavic medieval cultures Croatian Glagolitism was specific as it is the only Slavic literature that has preserved the original Glagolitic script invented by St. Cyril and as it emerged and developed in the bosom of the Roman church. Therefore, it was exposed to a strong Latin influence, in contrast to other Slavic literary cultures based on Cyrillo-Methodian tradition in which Greek influence was dominant. So we can say that Croatian Glagolitism was a specific historical phenomenon with the following characteristics: Glagolitic script, Church Slavonic language, western liturgy and jurisdiction of the Roman church. Croatian Glagolites have always been torn between their Cyrillo-Methodian heritage and the aspiration for legitimacy in the Western Church. They had to revise Old Church Slavonic texts translated from Greek and adapt them to the official Latin liturgical texts of the Western Church. We know that there were three main revisions. The first revision of Biblical texts, and their adaptation to Vulgate was carried out at the beginning of the 12th century, as witnessed by the Baška Fragments from this century (Reinhart 1990a, 1990b). The Croatian-Glagolitic texts were thoroughly revised for the second time in the second half of the 13th century. This revision, which was accompanied by the orthographic reform (Mareš 1985, Mihaljević 2009), is usually associated with the official recognition of Croatian Church Slavonic liturgy by pope Inocent IV in his rescripts to Philip, bishop of Senj (1248), and Fructuosus, bishop of Krk (1252), and with the introduction of the Franciscan plenary missal and breviary. Compiling their missals and breviaries, Croatian Glagolites used a combined approach. They

Until the beginning of the 14th century.

5 During the so-called golden period of Croatian Glagolitism. 
translated from Latin those texts which have not been translated, but they took over from older manuscripts the texts which they had inherited from the Cyrillo-Methodian period ${ }^{6}$ and adapted them to the Latin missal and breviary. However, this adaptation was only partial. In most cases they changed, according to the Latin model, only the beginning and the end, while the main (middle) part of the lection stayed intact (Tandarić 1993, 311). The third revision, and further adaptation to Latin texts, was carried out in the middle of the 14th century. Its centre was in the south, in the Zadar-Krbava region. Since it didn't reach the north-western part of the Glagolitic territory, it resulted in the division of the Croato-Glagolitic liturgical codices into two groups. The northern (Krk-Istra) group of codices, which is more conservative, preserves many texts which are based on Old Church Slavonic translation from Greek, while the southern (Zadar-Krbava) group is more inovative. Some manuscripts from the intermediate region of Vinodol and Gacka represent the transitional group with a mixed situation. It is worth pointing out here that even in the most representative manuscripts of the southern group the adaptation to Latin original was never fully completed (Tandarić 1993, 314). Therefore, even in them we can still find traces of older translation from Greek originals.

\section{CROATIAN CHURCH SLAVONIC LITERATURE TRANSLATED FROM LATIN}

In a short paper we don't have enough space to discuss in detail the Croatian Church Slavonic literature that has been translated from Latin, which is much more extensive than the literature translated from Greek. In addition to the translation of the Missal and the Breviary, a prominent place is occupied by different homiletic texts: Blagdanar = Sermons on Saints by Peregrinus of Opole; Quadragesimale by Jacobus de Voragine, the Discipulus of Johannes Herolt, etc. Fairly well represented are also late medieval genres of legends, visions, exempla, miracles and controversies, for example: Visio Tnugdali, Visio Philiberti, De morte prologus, Purgatorium s. Patricii, etc. Medieval Croatian readers had also at their disposal belletristic works such as the romances, ${ }^{7}$ late medieval didactic prose ${ }^{8}$ as well as juridical texts, ${ }^{9}$ amulets and even some medical prescriptions (Badurina Stipčević 2013, Dürrigl 2013).

\subsection{The Bridge between the West and the East}

Due to its position between the European West and East, Croatian Glagolitic literature has united the cultural products of both areas. It should be stressed that we are not dealing here with the mere coexistence of two different traditions on the same territory, but with their productive interaction and interpenetration as well. This is most clearly visible in non-liturgical Glagolitic miscellanies in which eastern (Byzantine) texts, translated from Greek, and western text, translated from Latin, Italian and Czech coexist. This specific dualism of Croatian Glagolitic literature enabled it to become a kind of spiritual mediator and bridge between the West and the East (Graciotti 1971, Hercigonja 2009). Croatian medieval literature was not only a receptive, but also an emissive factor in the European cultural sphere. Different Western-European texts had been translated from Latin or Italian into Church Slavonic in Croatia and then passed on to other Slavic literatures. Such are for example the apocryphal Gospel of Nicodemus, the Sunday Letter

\footnotetext{
Mostly biblical, but also some homiletic texts.

For example, the Romance of Troy.

For example: the Disticha Catonis, Elucidarius, the Fiore di virtu etc.

9 Canonical right, the Rule of St. Benedict etc.
} 
and the Romance of Troy. It is usually assumed that the Romance of Bovo d'Anton, the Romance of Lancelot and the Romance of Tristan, which are attested in Eastern Slavic manuscripts since the 16th century, are also of Croatian origin (Graciotti 1971, Hercigonja 2009). The same origin is also often assumed for the Romance of Alexander, but we have to admit that this is not certain and that the problem of its origin is a complex and controversial issue.

\section{THE WESTERN SLAVIC EPISODE}

Due to the work of Croatian Glagolites the Western Slavs could discover again the CyrilloMethodian liturgy, when in 1347 the king of Bohemia and the emperor of the Holy Roman Empire Karl IV, with the approval of the pope Klement VI, founded the Emmaus monastery in the suburb of Prague Na Slovanech and called Croatian Benedictine monks, who brought with them the Slavic liturgy of the Roman rite. In this monastery, different manuscripts had been written in Croatian angular Glagolitic script, not only in the Croatian Church Slavonic language, but in old Czech as well. The fragments of the Czech Glagolitic Bible from 1416, Comestor ${ }^{10}$ and Pasionál, ${ }^{11}$ have been preserved until today. Although the "Emmaus episode" had lasted a little less than a century, it had some influence on the Czech culture. According to Ludmila Pacnerova, the preserved manuscripts have a great significance for the history of the Czech language and literature because they have preserved text variants which are not attested in other manuscripts (Pacnerova 2008, 420). Moreover, it seems that the texts which were written in Emmaus were one of the impulses for the reform of Czech orthography carried out by Jan Hus (Mareš 1973). As can be seen from the texts preserved in Croatian Glagolitic miscellanies from the 15th and 16th centuries, Croatian monks in the Emmaus monastery had developed a fairly intensive translational activity. They translated different religious-didactic, homiletic, hagiographic, legendary and even scientific works from Old Czech into Croatian. Johannes Reinhart gives the following list of texts translated from Old Czech originals: Lucidar, Vitae from Pasionál, the Paradisus animae of Pseudo-Albertus Magnus, the Speculum humanae salvationis, two short texts of St. Bonaventura, three original works by Jan Hus, ${ }^{12}$ a commentary on the Ten Commandments by Tomáš ze Štítného and the Epistles of Pseudo-Hieronymus (Reinhart 1999, 2000a, 2000b and Mihaljević, Reinhart 2005, 44).

The activity of the Emmaus Glagolites was not restricted to Czech territory. In 1380 prince Konrad II the Gray called them to Silesia, and founded the monastery in Oleśnica for them. Ten years later king Wladislaw II Jagiello and his wife Jadwiga called them to Krakow and founded for them the monastery of the Holy Cross in the suburb Kleparz, in which the Slavic liturgy had survived almost a hundred years. Although the Catholic Slavonic liturgy in Poland died away with the downfall (collapse) of the monasteries in Oleśnica and Kleparz, there remained the consciousness (awareness, knowledge) that the Cyrillo-Methodian tradition was connected not only to Orthodox, but also to Catholic Church, which, according to Leszek Moszyński, had some influence on Polish cultural history (Moszyński 2004).

10 The collection of biblical stories.

11 The Old Czech version of Golden Legend.

12 The homily on the 13th Sunday after Whitsun, a commentary on the Ten Commandments entitled Výklad desatera božieho přikázanie and Provázek třípramenný. 


\section{ECHOES IN WESTERN EUROPE}

During the so-called "golden period" Croatian Glagolitism attracted some interest even in western non-Slavic European countries, mostly in Italy and France. Paradigmatic is the case of George of Slavonia (ca. 1355 - 1416) who, at the beginning of the 15th century, made the Glagolitic script and the Church Slavonic language known in France. George was born in Brežice, now Slovenia, but raised in the Glagolitic milieu in Krbava in Croatia, and then went to France. First he was a student and later a professor at Sorbonne and ended his career as a cathedral canon in Tours. He was a doctor of theology and a respectable author and copyist of Latin and Old French writings. In one of his manuscripts he reproduced the Glagolitic alphabet with names of letters and stated that it was called "Croatian". He also recorded several prayers, ${ }^{13}$ in Croatian Church Slavonic with Latin transcription, and the names of dioceses of his homeland in which the Mass was celebrated in the Church Slavonic language in the Latin script (Šanjek, Tandarić 1984).

Thanks to the publishing of Croatian Glagolitic books in well-known printing-offices in Venice, Glagolitic script had during the 16th century attracted the interest of different erudites and historians of the Renaissance period in Italy and France. They reproduced the Glagolitic alphabet in their encyclopaedic and historical publications, usually with names of letters and with comments about their phonetic realisations, their origin and sometimes even pointed out their similarities with other scripts, such as Greek, Armenian and Hebraic. ${ }^{14}$ In this way the Western Europe became acquainted with the script invented by St. Cyril. ${ }^{15}$

\section{REFERENCES}

Badurina Stipčević, Vesna (prir.). 2013. Hrvatska srednjovjekovna proza I. : Legende i romani. Zagreb.

Birnbaum, Henrik. 1996. How Did Glagolitic Writing Reach the Coastal Regions of Northwestern Croatia? In Croatica 42-44, 69-79.

Dürrigl, Marija-Ana (prir.). 2013. Hrvatska srednjovjekovna proza II. : Apokrifi, vizije, prenja, Marijini mirakuli. Zagreb.

Fučić, Branko. 1987. Granična područja glagoljice i ćirilice. In Brački zbornik 15, 17-28.

Graciotti, Sante. 1971. Hrvatska glagoljska književnost kao kulturni posrednik između evropskog Zapada i istočnih Slavena. In Slovo 21, 305-323.

Hercigonja, Eduard. 1975. Srednjovjekovna književnost. Zagreb.

Hercigonja, Eduard. 2006. Tropismena i trojezična kultura hrvatskoga srednjovjekovlja. Zagreb. Hercigonja, Eduard. 2009. Tisućljeće hrvatskoga glagoljaštva. Zagreb.

Mareš, F. V. 1973. Kyrillo-methodianische Wurzeln der tschechischen diakritischen Ortographie. In Anz. der Phil-hist. Klasse der Österreich. Akad. der Wissenschaften 110/3, 81-99.

Mareš, F. V. 1985. A Basic Reform of the Orthography at the Early Period of Croatian-Glagolitic Church Slavonic. In Stone, Gerald - Worth, Dean (eds.). The Formation of the Slavonic Literary Languages. Columbus, 177-181.

13 Our Father, Hail Mary, Apostles Creed and Nicaeno-Constantinopolitan Creed.

14 Eduard Hercigonja mentions explicitly Guillaume Postel and Blaise de Vigenèr from France and Giovanni Battista Palatino and Angelo Rocca from Italy (Hercigonja 2009, 115-116).

15 Although it was ascribed to St. Jerome (Alphabetum Hieronymianum), as it was common opinion at the time. 
Mihaljević, Milan. 2009. (Ortho)graphic Reforms in Croatian Glagolitic Texts. In Zašev, Evgenij (ed.). Sbornik s dokladi ot Meždunarodnata konferencija «Glagolica i kirilica - istorija i pismeni pametnici», Bratislava 6-7 juni 2007 g. Bratislava, 1-11.

Mihaljević, Milan. 2016. Tragovi južnoga puta. In Makedonski jazik 67 (to appear).

Mihaljević, Milan - Šimić, Marinka. 2013. Preslavizmi u hrvatskoglagoljskim tekstovima. In Turk,

Marija (ur.). A tko to ide? Hrvatski prilozi XV. međunarodnom slavističkom kongresu (Minsk, 20.-27. kolovoza 2013.). Zagreb, 11-23.

Moszyński, Leszek. 1986. Wpływ Wulgaty na kształt starochorwackiego Ewangeliarza z Omišlja. In Slovo 36, 111-122.

Moszyński, Leszek. 2004. Próba nowego spojrzenia na duchowe dziedzictwo krakowskiego głagolityzmu w średniowiecznej Polsce. In Dürrigl, Marija-Ana - Mihaljević, Milan - Velčić, Franjo (eds.). Glagoljica i hrvatski glagolizam. Zagreb - Krk, 309-318.

Nazor, Anica. 1985. Ćirilica u glagoljskim rukopisima. In Reinhart, Johannes (ed.). Litterae Slavicae Medii Aevi : Francisco Venceslao Mareš Sexagenario Oblatae. München, 241-252.

Nazor, Anica. 2000. Prožimanje glagoljice i ćirilice na hrvatskom prostoru. In Hercigonja, Eduard (ur.). Hrvatska i Europa : kultura, znanost i umjetnost. Sv. 2: Srednji vijek i renesansa (XIII XVI. stoljeće). Zagreb, 289-297.

Pacnerová, Ludmila. 2008. Staročeské literární památky a charvátská hranatá hlaholice. In Slovo 56-57, 405-420.

Petrović, Ivanka. 1988. Prvi susreti Hrvata s ćirilometodskim izvorištem svoje srednjovjekovne kulture. In Slovo 38, 5-54.

Reinhart, Johannes. 1990a. Eine Redaktion des kirchenslavischen Bibeltextes im Kroatien des 12. Jahrhunderts. In Wiener slavistisches Jahrbuch 36, 193-241.

Reinhart, Johannes. 1990b. Najstarije svjedočanstvo za utjecaj Vulgate na hrvatskoglagoljsku Bibliju. In Slovo 39-40, 45-52.

Šanjek, Franjo - Tandarić, Josip. 1984. Juraj iz Slavonije (oko 1355/60 - 1416.) profesor Sorbonne i pisac, kanonik i penitencijar stolne crkve u Toursu. In Croatica Christiana Periodica 13, 1-23. Štefanić, Vjekoslav. 1971. Determinante hrvatskog glagolizma. In Slovo 21, 13-30.

Tandarić, Josip. 1983. Hrvatskoglagoljski Apostol između Istoka i Zapada. In Croatica 14, 155-166. Valjavec, Matija. 1890. O prijevodu psalama u ńekijem rukopisima hrvatsko-srpsko i bugarskoslovenskijem. In Rad Jugoslavenske akademije znanosti i umjetnosti 98, 1-84; 99, 1-72; 100, $1-64$.

Vrana, Josip. 1975. Najstariji hrvatski glagoljski evanđelistar. Beograd.

SUMMARY: CROATIAN GLAGOLITISM BETWEEN THE WEST AND THE EAST. The Croato-Glagolitic literature based on Cyrillo-Methodian foundations was born at the end of the 9th, or at the beginning of the 10th century. Church Slavonic texts made their way to Croatia by two alternative routes - first from the north, i.e. directly from Moravia and Panonia, and later from the south, i.e. from Macedonia. Among Slavic medieval cultures Croatian Glagolitism was specific as it is the only Slavic literature that has preserved the Glagolitic script and as it emerged and developed in the bosom of the Roman church. Therefore, it was exposed to strong Latin influence, in contrast to other Slavic literary cultures based on Cyrillo-Methodian tradition, in which Greek influence was dominant. Croatian Glagolites have always been torn between their Cyrillo-Methodian heritage and the aspiration for legitimacy in the Western Church. They had to revise Old Church Slavonic texts translated from Greek and adapt them to the official Latin liturgical texts of the Western Church. The first adaptation of Biblical texts to Vulgate was carried out at the beginning of the 12th century. The Croatian-Glagolitic texts were thoroughly revised 
for the second time in the second half of the 13th century, and for the third time in the middle of the 14th century. The Croatian Church Slavonic literature translated from Latin is much more extensive than that translated from Greek. In addition to the Missal, the Breviary and different homiletic texts, the late medieval genres of visions, exempla, miracles and controversies are also fairly well represented, as well as literary works such as romances, late medieval didactic prose, juridical texts, amulets and even some medical prescriptions. Due to its position between the European West and East, Croatian Glagolitic literature became a kind of spiritual mediator and a bridge between the West and the East. Different WesternEuropean texts had been translated from Latin or Italian into Church Slavonic in Croatia and then passed on to other Slavic literatures. Due to the work of Croatian Glagolites the Western Slavs could in the 15th century discover again the Cyrillo-Methodian liturgy, when the king of Bohemia and the emperor of the Holy Roman Empire Karl IV called Croatian Benedictine monks to Prague. During the so-called "golden period" Croatian Glagolitism attracted some interest even in western non-Slavic European countries (Italy, France).

\author{
dr. sc. Milan Mihaljević \\ Staroslavenski institut \\ Demetrova 11 \\ 10000 Zagreb \\ Croatia \\ mihalj@stin.hr
}

